Jurnal Common | Volume 4 Nomor 1 | Juni 2020

Website: https://ojs.unikom.ac.id/index.php/common

DOI Jurnal: https://doi.org/10.34010/common

DOI Artikel: https://doi.org/10.34010/common.v4i1.2688

\title{
ANALISIS FRAMING PEMBERITAAN PEMBANGUNAN POJOK DILAN PADA MEDIA PIKIRAN-RAKYAT.COM DAN NEWS.DETIK.COM/JAWABARAT
}

\author{
Musniyah Ayunita Muzakkirr ${ }^{1}$, Rana Akbari Fitriawan ${ }^{2}$ \\ ${ }^{1,2}$ Program Studi Ilmu Komunikasi, Fakultas Komunikasi dan Bisnis, Universitas Telkom, Jl. Telekomunikasi \\ J1. Terusan Buah Batu, Sukapura, Kec. Dayeuhkolot, Bandung, 40257, Indonesia \\ E-Mail: \\ $\underline{\text { ayunitamusniyah@student.telkomuniversity.ac.id }}^{1}, \underline{\text { ranaakbar@telkomuniversity.ac.id }}^{2}$
}

\begin{abstract}
The establishment of the Dilan's Corner became an issue that caused a pros and cons polemic among the people of Bandung City. Because there is news value from this Dilan's Corner establishment issue, local media such as pikiran-rakyat.com and news.detik.com/jawabarat raised this news. These two media certainly have differences in constructing existing reality. This study aims to determine how the online media, pikiran-rakyat.com.com and news.detik.com/jawabarat framing news related to the construction of Dilan's Corner in Bandung using the framing model of Zhondang Pan and Gerald M. Kosicki. In this study, qualitative research methods with a constructionist paradigm are used. The results of this study are different news framing from the two media. Pikiran-rakyat.com.com tends to highlight the main resource person, Ridwan Kamil as the Governor of West Java as well as the initiator of Dilan Corner so that the alignments can be seen from pikiran-rakyat.com.com, while news.detik.com/jawabarat seems to be more taking sides in the public interest that is marked by the selection of varied and inclined sources to show their resistance to the Dilan's Corner establishment.
\end{abstract}

Keywords: Framing, Zhondang Pan dan Gerald M. Kosicki, Pojok Dilan, Ridwan Kamil

\begin{abstract}
Abstrak
Pembangunan Pojok Dilan menjadi isu yang menimbulkan polemik pro dan kontra di tengah-tengah masyarakat Kota Bandung. Karena terdapat nilai berita dari isu pembangunan Pojok Dilan ini, maka media-media lokal seperti pikiran-rakyat.com dan news.detik.com/jawabarat mengangkat pemberitaan ini. Dua media tersebut tentu memiliki perbedaan dalam mengkonstruksi realitas yang ada. Penelitian ini bertujuan untuk mengetahui bagaimana media online pikiran-rakyat.com.com dan news.detik.com/jawabarat membingkai berita terkait pembangunan Pojok Dilan di Bandung menggunakan framing model Zhondang Pan dan Gerald M. Kosicki. Dalam penelitian ini, digunakan metode penelitian kualitatif dengan paradigma konstruksionis. Hasil dari penelitian ini adalah pembingkaian berita yang berbeda dari dua media tersebut. Pikiran-rakyat.com cenderung menonjolkan narasumber utama yaitu Ridwan Kamil selaku Gubernur Jawa Barat sekaligus penggagas Pojok Dilan sehingga terlihat keberpihakan dari pikiran-rakyat.com.com. Sedangkan news.detik.com/jawabarat terlihat lebih memihak pada kepentingan publik ditandai dengan pemilihan narasumber yang variatif dan condong untuk menunjukkan sikap penolakan dalam pembangunan Pojok Dilan.
\end{abstract}

Kata Kunci: Framing, Zhondang Pan dan Gerald M. Kosicki, Pojok Dilan, Ridwan Kamil 
Website: https://ojs.unikom.ac.id/index.php/common

DOI Jurnal: https://doi.org/10.34010/common

DOI Artikel: https://doi.org/10.34010/common.v4i1.2688

\section{Pendahuluan}

Masyarakat Kota Bandung kembali dihadiahi satu pojok Taman Saparua yang dinilai Ridwan Kamil mampu memberikan dampak positif bagi masyarakat Bandung khususnya kaum milenial di Bandung. Berdasarkan tayang perdananya film fenomenal remaja di Indonesia yaitu Film Dilan 1991 pada tanggal 24 Februari disambut sangat baik oleh Gubernur Jawa Barat, Ridwan Kamil. Bahkan Ridwan Kamil turut serta dalam memerankan tokoh seorang guru di Film Dilan 1991 dan mengakui Film Dilan 1991 sebagai karya anak bangsa yang patut diapresiasi luar biasa karena berangkat dari sebuah novel yang sarat akan nilai literasi kemudian menjadi sebuah film dalam negeri yang cukup fenomenal serta menggambarkan suasana Kota Bandung. (Rizal, 2019)

Film Dilan 1991 yaitu film kedua yang tayang setelah Film Dilan 1990 yang disutradarai oleh Fajar Bustomi serta Pidi Baiq juga selaku penulis dalam novel Dilan 1990 dan 1991 ini. Film Dilan yang diperankan oleh Iqbal Ramadhan sebagai Dilan dan Vanesha Prescilla sebagai Milea menceritakan kisah romantisme percintaan pada zaman dahulu sebelum adanya media online (gadget) seperti saat sekarang ini. Kisah cinta yang dibumbui oleh puisi-puisi yang puitis dan menjadi daya tarik bagi kaum milenial dan juga orang tua yang tahun 90 pernah merasakannya. (FilmIndonesia.or.id, 2019)

Namun di balik fenomenalnya Film Dilan, muncul pro kontra di masyarakat berkaitan dengan rencana pembangunan Taman Dilan. Seperti yang diberitakan media, bahwa Ridwan Kamil berencana membangun sebuah taman untuk mengapresiasi karya literasi anak bangsa. Namun, beberapa pengamat sangat menyayangkan keputusan Gubernur Jawa Barat terhadap spesialisasi hari Dilan yang jatuh pada tanggal 24 Februari dan akan dibuatkan Taman Dilan sebab Dilan adalah tokoh fiksi dalam novel maupun film.

Secara simbolis, peletakan batu pertama Pojok Dilan ini telah dilakukan pada tanggal 24 Februari 2019 lalu oleh Gubernur Jawa Barat, Ridwan Kamil, bersama dengan Menteri Pariwisata Arief Yahya serta para pemain Film Dilan 1991. Dimana penampakan Pojok Dilan di salah satu sudut Taman Saparua setelah diresmikan oleh Ridwan Kamil selaku penggagas Pojok Dilan adalah sebagai berikut:

\section{Gambar 1.1 Lokasi pembangunan Pojok Dilan (bandung.kompas.com)}

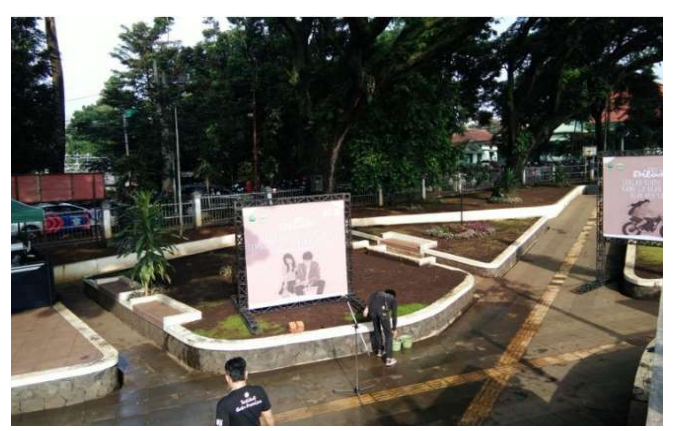

Sehingga berdasarkan pemaparan sebelumnya, Pojok Dilan sebagai bentuk apresiasi terhadap karya literasi bahkan film di Indonesia. Di mana Gubernur Jawa Barat ini berharap dengan adanya Dilan Corner bisa menjadi tempat belajar sastra, baik menulis maupun membaca bagi siapapun. (Solehudin, 2019)

Setelah diletakkannya secara simbolis batu pertama pembangunan Pojok Dilan, membuat sejumlah pengamat publik angkat bicara. Kemudian pengamat komunikasi politik UPI Karim Auryadi berpendapat bahwa pembangunan Pojok Dilan tidak ada momentum sama sekali sehingga tidak perlu dibangun Pojok Dilan, selain itu dalam Film Dilan tersebut tidak ada korelasi sama sekali dengan konteks Jawa Barat, di satu sisi cerita Dilan merupakan cerita percintaan remaja biasa. Selain itu 
Website: https://ojs.unikom.ac.id/index.php/common

DOI Jurnal: https://doi.org/10.34010/common

DOI Artikel: https://doi.org/10.34010/common.v4i1.2688

masih dikutip melalui detik.com, pengamat kebijakan publik Unpar, Asep Warlan, berpandangan bahwa ada tokoh lain yang lebih layak dibuatkan monumen seperti itu. Bukan tokoh fiktif yang dimonumenkan. (Solehudin, 2019)

Namun, berdasarkan kontroversi Pojok Dilan yang semakin berlanjut, Gubernur Jawa Barat, Ridwan Kamil, menanggapi dengan tegas di beberapa media publik bahkan di akun instagram pribadinya bahwa Pojok Dilan dibangun untuk mewadahi kegiatan literasi warga kota. "Itu sudut literasi, untuk komunitas milenial rajin membaca novel, sastra, dan film" tutur Ridwan Kamil. (Ranawati, 2019)

Dalam pemberitaan yang dilakukan oleh media lokal maupun nasional, pembangunan Pojok Dilan mendapat reaksi keras dari masyarakat, komentar netizen di media sosial, serta budayawan yang menganggap masih banyak tokoh penting hingga ahli tata kota. Mayoritas menganggap rencana Ridwan Kamil perlu dilakukan pengkajian ulang karna minimnya urgensi bagi masyarakat.

Maka dari itu, hal inilah yang nantinya akan penulis teliti lebih mendalam dengan melihat bagaimana media pikiranrakyat.com dan news.detik.com/jawabarat sebagai objek penelitian dalam membingkai suatu fakta yang disajikan dalam bentuk berita tersebut. Sehingga penulis mengetahui perbedaan di antara kedua media online tersebut dalam pembingkaian berita pembangunan Pojok Dilan di Bandung.

Untuk mengetahui bagaimana pikiranrakyat.com dan news.detik.com/jawabarat dalam membingkai berita pembangunan Pojok Dilan mulai berita itu muncul, maka digunakan analisis framing. "Analisis framing cocok digunakan untuk melihat konteks sosial-budaya suatu wacana, khususnya hubungan antara berita dan ideologi, yakni proses atau mekanisme mengenai bagaimana berita membangun, mempertahankan, mereproduksi, mengubah dan meruntuhkan ideologi." (Mulyana dalam Eriyanto, 2012: XV).

\subsection{Fokus Penelitian}

Berdasarkan uraian di atas, fokus penelitian ini adalah bagaimana media online pikiran-rakyat.com dan news.detik.com/jawabarat membingkai berita terkait pembangunan Pojok Dilan di Bandung menggunakan framing model Zhondang Pan dan Gerald M. Kosicki.

\subsection{Tujuan Penelitian}

Berdasarkan rumusan masalah di atas, tujuan penelitian ini adalah untuk mengetahui bagaimana media online pikiran-rakyat.com dan news.detik.com/jawabarat membingkai berita terkait pembangunan Pojok Dilan di Bandung menggunakan framing model Zhondang Pan dan Gerald M. Kosicki.

\section{Kajian Pustaka dan Kerangka Pemikiran}

\subsection{Jurnalistik Online}

Jurnalistik online itu sendiri berasal dari dua suku kata dengan makna yang berbeda, yakni jurnalistik dan online. Pengertian jurnalistik menurut beberapa ahli ialah sebagai berikut:

Assegaf (dalam Sumadiria, 2005: 2) menyebutkan bahwa jurnalistik adalah kegiatan dalam menyiapkan, mengedit, dan menulis untuk surat kabar, majalah atau media lainnya. Sedangkan Djen Amar (dalam Sumadiria, 2005: 3) menjelaskan bahwa jurnalistik adalah proses mengumpulkan, mengolah, dan menyebarkan berita kepada khalayak. 
Website: https://ojs.unikom.ac.id/index.php/common

DOI Jurnal: https://doi.org/10.34010/common

DOI Artikel: https://doi.org/10.34010/common.v4i1.2688

Kemudian menurut Onong U. Effendi (dalam Muhtadi, 2016: 16) menyebutkan bahwa jurnalistik adalah sebuah keterampilan dalam mengolah bahan berita dimulai dari peliputan hingga penyusunan berita yang kemudian disebarluaskan kepada khalayak masyarakat. Berdasarkan perbedaan definisi terkait jurnalistik itu sendiri, dapat ditarik kesimpulan bahwan jurnalistik sebuah kegiatan mencari berita kemudian diolah lalu disajikan kepada khalayak secepat dan seluas mungkin.

Kemudian online itu sendiri merupakan bahasa inggris dari daring (dalam jaringan). Namun penyebutannya lebih sering menggunakan kata online. Online yang dimaksud dalam jurnalistik online ini adalah dalam hal media yang digunakan dalam penyebaran berita yaitu media online. secara teknis media online (Muhtadi, 2016: 78) didefinisikan sebagai media yang berbasis telekomunikasi dan multimedia yang secara fisik difasilitasi komputer dan internet.

Sehingga dapat ditarik kesimpulan bahwa jurnalistik online adalah kegiatan dalam mencari, mengolah, kemudian menyebarkan berita kepada khalayak menggunakan media yang tehubung dengan internet agar dapat diakses dan diterima oleh khalayak seluas-luasnya dan secepat mungkin.

\subsection{Konstruksi Realitas Media}

Ritzer (dalam Bungin, 2008: 11) menjelaskan bahwa ide dasar semua teori dalam paradigma definisi sosial ialah manusia sebagai aktor yang kreatif terhadap realitas sosialnya, dimana setiap tindakan manusia tidak sepenuhnya berdasarkan norma - norma, kebiasaan kebiasaan, nilai - nilai, dan sebagainya, melainkan tecakup dalam fakta sosial berupa tindakan yang tergambarkan struktur dan pranata sosialnya. Namun Bungin (2008: 12) merumuskan bahwa individu bukanlah manusia korban fakta sosial, melainkan mesin produksi sekaligus reproduksi yang kreatif melalui kekuatan konstruksi sosial terhadap dunia sosial di sekelilingnya.

Maka dari itu untuk dapat memahami konstruksi atas realitas sosial (social construction of reality). Peter L. Berger dan Thomas Luckmann menggambarkan konstruksi realitas sosial sebagai proses sosial melalui tindakan dan interaksi, dimana individu secara terus-menerus menciptakan suatu realitas yang dimiliki dan dialami secara subyektif. Berger dan Luckmann (dalam Bungin, 2008: 14-15) memisahkan pemahaman 'kenyataan' dan 'pengetahuan' dalam realitas sosial itu sendiri dan juga menyatakan terjadi dialetika antara indovidu menciptakan masyarakat dan masyarakat menciptakan individu. Dimana proses dialetika ini terjadi melalui tahap eksternalisasi, objektivasi, dan internalisasi.

Dengan demikian, tahap eksternalisasi (Bungin, 2008: 16) adalah tahap yang berlangsung ketika produk sosial tercipta di dalam masyarakat, kemudian individu itu sendiri melakukan eksternalisasi atau penyesuaian diri ke dalam dunia sosiokulturalnya sebagai bagian dari produk manusia.

Kemudian tahap obyektivasi, dimana obyektivasi terjadi melalui penyebaran opini sebuah produk sosial yang berkembang di masyarakat tentang produk sosial tanpa perlu ada tatap muka, serta hal terpenting dalam tahap ini adalah pembuatan signifikasi atau pembuatan tanda-tanda oleh manusia (Berger dan Luckmann dalam Bungin, 2008: 17).

Tahap terakhir yaitu internalisasi, dimana titik awal dari tahap ini ialah pemahaman atau penafsiran yang langsung dari suatu peristiwa obyektif untuk digunakan sebagai pengungkapan suatu makna. 
Website: https://ojs.unikom.ac.id/index.php/common

DOI Jurnal: https://doi.org/10.34010/common

DOI Artikel: https://doi.org/10.34010/common.v4i1.2688

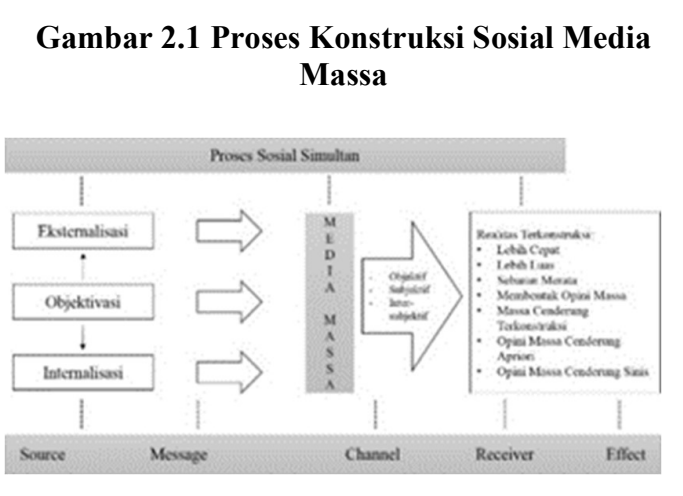

Sumber: Konstruksi Sosial Media Massa (Bungin, 2008:194)

Berdasarkan gambar di atas, proses dari kontruksi sosial media massa, dan proses kelahiran konstruksi sosial media massa melewati beberapa tahap sebagai berikut: (a) tahap menyiapkan materi konstruksi; (b) tahap sebaran konstruksi; (c) tahap pembentukan konstruksi realitas; dan (d) tahap konfirmasi.

\subsection{Berita dalam Sudut Pandang Konstruktivis}

Berita dalam pandangan konstruksi sosial, dianggap sebagai peristiwa atau fakta yang bukan dalam arti riil. Dimana realitas tidak begitu saja dijadikan sebagai berita melainkan menjadi produk dari interaksi antara wartawan dan fakta (Eriyanto, 2012: 20). Fakta/realitas menurut Carey (dalam Eriyanto, 2012: 23) bukanlah sesuatu yang terberi, melainkan ada dalam benak kita, yang melihat fakta tersebut, dimana kitalah yang memberi definisi dan menentukan fakta tersebut sebagai realitas.

Kemudian dalam pandangan kontruksionis, media juga dianggap sebagai subjek yang mengkonstruksi realitas, lengkap dengan pandangan, bias, dan pemihakannya. Sebab media bukan hanya memilih peristiwa dan menentukan sumber berita, melainkan juga berperan dalam mendefinisikan aktor dan peristiwa (Eriyanto, 2012: 26 - 27).

Sehingga Daniel C. Hallin dan Paolo Mancini (dalam Eriyanto, 2012: 29) merumuskan bahwa dalam sudut pandang konstruksionis, berita adalah hasil dari konstruksi sosial yang selalu melibatkan pandangan, ideologi, dan nilai - nilai dari wartawan dan media.

\subsection{Analisis Framing Zhongdang Pan dan M. Kosicki}

Menurut Zhondang Pan dan Gerald M. Kosicki (dalam Eriyanto, 2012: 79) mengemukakan bahwa framing adalah sebuah strategi konstruksi dan memproses berita dimana perangkat kognisi yang digunakan dalam mengkode informasi, menafsirkan peristiwa, dan dihubungkan dengan rutinitas dan konvensi pembentukan berita. Framing Pan \& Kosicki menggunakan empat perangkat dalam menganalisis teks berita. Pendekatan dari keempat perangkat tersebut digambarkan dalam bentuk skema sebagai berikut:

Tabel 3.1 Skema Framing Model Pan dan Kosicki

\begin{tabular}{|c|c|c|}
\hline Struktur & $\begin{array}{c}\text { Perangkat } \\
\text { Framing }\end{array}$ & $\begin{array}{c}\text { Unit } \\
\text { Pengamat } \\
\text { an }\end{array}$ \\
\hline $\begin{array}{l}\text { SINTAKS } \\
\text { IS } \\
\text { Cara } \\
\text { wartawan } \\
\text { menyusun } \\
\text { fakta }\end{array}$ & $\begin{array}{l}\text { 1. Skema } \\
\text { berita }\end{array}$ & $\begin{array}{l}\text { Headline, } \\
\text { lead, latar } \\
\text { informasi, } \\
\text { kutipan } \\
\text { sumber, } \\
\text { pernyataa } \\
\text { n, penutup }\end{array}$ \\
\hline $\begin{array}{l}\text { SKRIP } \\
\text { Cara } \\
\text { wartawan } \\
\text { mengisah } \\
\text { kan fakta }\end{array}$ & $\begin{array}{l}\text { 2. Kelengka } \\
\text { pan berita }\end{array}$ & $5 \mathrm{~W}+1 \mathrm{H}$ \\
\hline
\end{tabular}


Website: https://ojs.unikom.ac.id/index.php/common

DOI Jurnal: https://doi.org/10.34010/common

DOI Artikel: https://doi.org/10.34010/common.v4i1.2688

\begin{tabular}{|c|c|c|}
\hline $\begin{array}{l}\text { TEMATI } \\
\text { K } \\
\text { Cara } \\
\text { wartawan } \\
\text { menulis } \\
\text { fakta }\end{array}$ & $\begin{array}{ll}\text { 3. Detail } \\
\text { 4. Koherens } \\
\text { i } \\
\text { 5. Bentuk } \\
\text { kalimat } \\
\text { 6. Kata } \\
\text { ganti }\end{array}$ & $\begin{array}{l}\text { Paragraf, } \\
\text { proposisi, } \\
\text { kalimat, } \\
\text { hubungan } \\
\text { antar } \\
\text { kalimat }\end{array}$ \\
\hline $\begin{array}{l}\text { RETORIS } \\
\text { Cara } \\
\text { wartawan } \\
\text { menekank } \\
\text { an fakta }\end{array}$ & $\begin{array}{l}\text { 7. Leksikon } \\
\text { 8. Grafis } \\
\text { 9. Metafora }\end{array}$ & $\begin{array}{l}\text { Kata, } \\
\text { idiom, } \\
\text { gambar/fo } \\
\text { to, grafik }\end{array}$ \\
\hline
\end{tabular}

Sumber: Eriyanto (2012: 295)

Di bawah ini adalah penjelasan mengenai tentang unit-unit pengamatan pada analisis framing model Zhongdang Pan dan Gerald M. Kosicki (dalam Eriyanto, 2012: 295 - 304):

1. Sintaksis adalah susunan kata atau frase dalam kalimat. Sintaksis dalam wacana berita menunjuk pada pengertian susunan dan bagian dalam berita seperti headline (berita utama atau judul), lead (kalimat pembuka berita), latar informasi, sumber, dan penutup sedangkan bentuk sintaksis paling populer adalah struktur piramida terbalik meliputi judul headline, lead, episode, latar, dan penutup, dimana sintaksis ini berguna memberi petunjuk tentang bagaimana wartawan memaknai peristiwa dan kemana berita tersebut akan dibawa.

2. Struktur skrip ini adalah pola $5 \mathrm{~W}+1 \mathrm{H}$ (who, what, where, when, why, dan how). Unsur kelengkapan berita ini dapat menjadi penanda framing yang penting, walaupun pola ini tidak selalu dijumpai dalam setiap berita. Tapi tujuan menganalisis skrip ini untuk mengetahui cara wartawan atau media mengisahkan fakta kedalam bentuk berita.

3. Tematik, adalah bagaimana fakta itu ditulis kemudian bagaimana kalimat yang dipakai serta bagaimana menempatkan dan menulis sumber ke dalam teks berita secara keseluruhan.

4. Retoris, adalah menggambarkan pemilihan gaya atau kata yang dipilih oleh wartawan untuk menekankan arti yang ingin ditonjolkan oleh wartawan tersebut, salah satunya dengan penggunaan kata konotasi atau kata yang bukan makna sebenarnya. Selain itu penggunaan gambar atau foto untuk menunjukkan penekanan dari konstruksi berita yang dihasilkan.

\section{Objek dan Metode Penelitian}

Pendekatan analisis yang digunakan dalam penelitian ini adalah analisis framing model Zhongdang Pan dan Gerald M. Kosicki. Menurut Pan dan Kosicki (dalam Eriyanto, 2012: 290), framing didefiniskan sebagai proses membuat suatu pesan menjadi lebih menonjol, menempatkan informasi lebih daripada yang lain sehingga khalayak lebih tertuju pada pesan tersebut. Secara sederhana, framing dapat digunakan untuk mengetahui dan melihat bagaimana sebuah realitas diseleksi dan dibingkai oleh sebuah media.

Jadi berdasarkan data yang dikumpulkan berupa kata-kata dan gambar maka penulis mendeskripsikan hasil penelitian dengan menggunakan kata-kata tertulis kepada objek penelitian dengan analisis teks media framing yang terkandung dalam naskah berita media online pikiran-rakyat.com dan news.detik.com/jawabarat terkait pemberitaan Pembangunan Pojok Dilan di Bandung. Sehingga analisis yang penulis gunakan lebih menekankan pada bagaimana sebuah pemberitaan dibentuk oleh sebuah media yang menjadi objek dan pemberitaan penting inilah yang menjadi 
Website: https://ojs.unikom.ac.id/index.php/common

DOI Jurnal: https://doi.org/10.34010/common

DOI Artikel: https://doi.org/10.34010/common.v4i1.2688

salah satu aspek yang ingin diketahui masyarakat serta membandingankan cara penyajian berita antara pikiran-rakyat.com dan news.detik.com/jawabarat.

\section{Hasil dan Pembahasan}

Berdasarkan hasil analisis yang dilakukan peneliti pada media online pikiran-rakyat.com dan news.detik.com/jawabarat, akan terlihat bagaimana kedua media tersebut mengkonstruksi suatu peristiwa yang sama, namun menghasilkan pembingkaian yang berbeda dalam teks berita. Berita yang peneliti pilih merupakan berita yang berkaitan dengan pembangunan Pojok Dilan. Periode waktu berita yang peneliti pilih adalah dari bulan Februari hingga Maret 2019, dimana periode tersebut merupakan awal kasus Pojok Dilan muncul dalam portal berita, sampai akhirnya tidak dipermasalahkan lagi oleh media publik karena hasil keputusan dari Ridwan Kamil yang akan tetap membangun Pojok Dilan.

Berdasarkan struktur sintaksis, menurut analisis peneliti dari enam naskah berita yang diteliti, dimana masing-masing tiga naskah berita untuk pikiran-rakyat.com dan news.detik.com/jawabarat, terdapat lima berita yang menggunakan headline dengan kalimat bukan pernyataan langsung dari narasumber dan hanya terdapat satu berita yang menggunakan headline yang diambil dari pernyataan langsung narasumber. Judul yang menggunakan pernyataan langsung ini terlihat pada media news.detik.com/jawabarat yang berjudul "Polemik Pembangunan Dilan Corner, DPRD Jabar: Batalkan Saja".

Headline yang digunakan pada kelima naskah berita ini, lebih menonjolkan kepada apa yang terjadi pada isi berita, dimana tiga di antaranya menyebutkan narasumber pada headline berita. Judul yang menyebutkan narasumber terdapat pada media pikiran-rakyat yang berjudul "Dongkrak Pariwisata, Ridwan Kamil akan Bangun Taman Dilan", "Ridwan Kamil Meradang Ditanya Urgensi Sudut Dilan", dan pada media news.detik.com/jawabarat dengan judul "Korban banjir Kritik Ridwan Kamil Soal Pembangunan Dilan Corner". Kemudian dua sisanya hanya menggunakan headline yang menjelaskan inti dari berita tanpa memaparkan narasumber di judulnya.

Menurut Eriyanto (2012: 296) menyebutkan bahwa headline ialah aspek sintaksis berita dengan tingkat kemenonjolan yang tinggi untuk menunjukkan kecenderungan dari berita sehingga mempunyai fungsi framing yang kuat. Selain itu headline menunjukkan bagaimana wartawan mengkonstruksi suatu isu untuk menekankan suatu makna tertentu. Dalam hal ini, headline pikiranrakyat.com cenderung menggunakan narasumber yang berpihak pada pembangunan Pojok Dilan yang penyajian headlinenya tanpa pernyataan langsung dan terkesan ingin menunjukkan nilai positif dan keadaan sebenarnya dari pembangunan Pojok Dilan. Sedangkan headline yang digunakan news.detik.com/jawabarat, pemilihan narasumber cenderung kepada pihak yang kontra terhadap pembangunan Pojok Dilan dan lebih menekankan kepada aspek polemik pembangunan Pojok Dilan. Namun berdasarkan kedua media tersebut, pikiran-rakyat.com dan news.detik.com/jawabarat sama-sama menekankan isi berita yang ingin disampaikan.

Lead dari tiga berita pikiranrakyat.com yang diambil dua di antaranya yang menunjukkan kalimat yang menerangkan secara langsung dari judul yang diberikan. Satu berita lainnya yaitu berita pertama, inti dari berita tersebut disimpan pada paragraf kedua. Kemudian penggunaan lead berita 
Website: https://ojs.unikom.ac.id/index.php/common

DOI Jurnal: https://doi.org/10.34010/common

DOI Artikel: https://doi.org/10.34010/common.v4i1.2688

news.detik.com/jawabarat semuanya menerangkan secara langsung sesuai dengan judul masing-masing. Pada lead berita pertama media pikiran-rakyat.com lebih menjelaskan kepada rencana pembangunan Pojok Dilan. Sedangkan, lead berita pertama dari news.detik.com/jawabarat lebih menjelaskan kepada pihak yang tidak setuju pada pembangunan Pojok Dilan. Sehingga terlihat bahwa pembangunan Pojok Dilan dimaknai berbeda oleh kedua media ini.

Kemudian latar informasi dari kedua media online ini menunjukkan perbedaan karena pikira-rakyat.com lebih menekankan kepada isu pembangunan Pojok Dilan bermanfaat menurut Ridwan Kamil sedangkan latar belakang news.detik.com/jawabarat cenderung menunjukkan pembangunan Pojok Dilan merugikan masyarakat.

Terkait pengutipan narasumber, Eriyanto (2012: 298-299) menyebutkan terdapat tiga hal perangkat framing dalam pengutipan sumber, yaitu dengan mengklaim validitas agar tidak menunjukkan omong kosong melainkan didukung oleh ahli yang berkompenten, menghubungkan poin tertentu dari pandangannya dengan pejabat berwenang, dan mengecilkan pandangan tertentu untuk memperlihatkan bahwa pandangan tersebut menyimpang. Dalam pemilihan narasumber, kedua media cukup signifikan berbeda karena pikiran-rakyat.com cenderung menggunakan narasumber yang sama di setiap berita. Sedangkan news.detik.com/jawabarat cenderung lebih variatif.

Pada ketiga berita pikiran-rakyat.com, Ridwan Kamil menjadi narasumber utama, hanya saja pada berita kedua dan ketiga menambahkan narasumber tambahan seperti pada berita kedua terkait Ridwan Kamil yang meradang soal pembangunan
Pojok Dilan, di lain sisi menyebutkan pandangan kontra terhadap pembangunan Pojok Dilan oleh pengamat sosial dan akademisi Universitas Pasundan, Wim Tohari Daniealdi. Kemudian pada berita ketiga menambahkan tanggapan Kabar Nurdialis sebagai Kepala Badan Pengelola Keuangan dan Aset Daerah (BPKAD) terkait anggaran Pemerintah Provinsi Jawa Barat dalam merevitalisasi GOR Saparua.

Sedangkan news.detik.com/jawabarat menggunakan narasumber yang bervariatif dan cenderung menggunakan narasumber yang kontradiktif, seperti pada berita pertama news.detik.com/jawabarat menggunakan narasumber Dendi Jamaluddin Malik sebagai salah satu warga yang terkena dampak banjir di Kelurahan Andir yang menunjukkan kritik terhadap pembangunan Pojok Dilan. Sedangkan pada berita kedua, menggunakan narasumber petugas keamanan, tanggapan dari pakar komunikasi politik, Karim Suryadi, dan mengutip pernyataan Ridwan Kamil saat melakukan peresmian. Dan pada berita ketiga, News.detik.com/jawabarat membeberkan kritisi dari pihak DPRD Jawa Barat itu sendiri, yaitu Anggota Komisi IV DPRD Jawa Barat, Daddy Rohanady dan Wakil Ketua DPRD Jawa Barat, Irfan Suryanagara. Berdasarkan struktur skrip, pikiran-rakyat.com dan news.detik.com/jawabarat secara umum sudah memenuhi syarat $5 \mathrm{~W}+1 \mathrm{H}$.

Berdasarkan struktur tematik, pikiranrakyat.com dan new.detik.com/jawabarat, jika dilihat dari jumlahnya, kedua media ini cenderung membahas dua sampai tiga tema. Pada berita kedua pikiran-rakyat.com terdapat dua paragraf yang tidak mendukung pada tema utama dimana tema utamanya membahas tentang tanggapan dan sikap Ridwan Kamil yang emosional terhadap pembangunan Pojok Dilan. Sedangkan pada berita kedua news.detik.com/jawabarat terdapat dua 
Website: https://ojs.unikom.ac.id/index.php/common

DOI Jurnal: https://doi.org/10.34010/common

DOI Artikel: https://doi.org/10.34010/common.v4i1.2688

paragraf yang kurang mendukung pada tema utama dimana tema utama dari berita ini ialah menunjukkan kondisi dari pembangunan Pojok Dilan pasca peresmian sementara news.detik.com/jawabarat menambahkan tanggapan kontra dari pakar komunikasi politik.

Berdasarkan struktur retoris, terdapat bahasa yang cukup provokatif dalam berita pikiran-rakyat.com.com dan news.detik.com/jawabarat untuk menekankan suatu makna. Salah satunya seperti "receh", "eksis", "menggemborgemborkan", "lebay", "bertelanjang dada". Namun, setelah melakukan analisis penelitian terhadap kata idiom atau konotasi yang digunakan dan dituangkan menggunakan bahasa provokatif, maka diperoleh hasil media pikiranrakyat.com.com lebih banyak menggunakan kata idiom tersebut dibandingkan dengan news.detik.com/jawabarat. Sehingga penggunaan bahasa provokatif ini menunjukkan kecenderungan penekanan makna tertentu yang ingin diperlihatkan oleh pikiran-rakyat.com.com melalui teks berita yang disajikan.

Kemudian penggunaan foto pada teks berita pikiran-rakyat.com.com selalu menyesuaikan dengan judul atau isi berita atau tokoh yang dibahas dalam berita. Hanya saja beberapa foto yang digunakan pikiran-rakyat.com tidak menggunakan dokumentasi dari wartawan pikiranrakyat.com.com melainkan diambil dari dokumentasi Humas Pemerintah Provinsi Jawa Barat dan beberapa tanpa keterangan caption foto. Hanya saja dari ketiga berita pikiran-rakyat.com.com yang dianalisis semua gambarnya memakai foto Ridwan Kamil dengan sudut pengambilan gambar $\&$ mimik wajah yang berbeda serta terdapat pengulangan gambar pada berita kedua yang berjudul "Ridwan Kamil Meradang Ditanya Urgensi Sudut Dilan” dan berita ketiga berjudul "Sudut Dilan Masuk Revitalisasi GOR Saparua Senilai Rp 5,9 miliar".

Pada berita news.detik.com/jawabarat, foto yang digunakan juga menyesuaikan judul dan isi berita hanya saja sedikit lebih variatif karena sudut pandang berita news.detik.com/jawabarat lebih menekankan pada pihak kontra terhadap pembangunan Pojok Dilan. Misalnya pada berita pertama news.detik.com/jawabarat yang berjudul "Korban Banjir Kritik Ridwan Kamil Soal Pembangunan Pojok Dilan" menggunakan foto masyarakat yang sedang berdemo, kemudian pada berita kedua yang berjudul "Dilan Corner Menuai Pro Kontra, Begini Penampakannya Saat Ini” menggunakan foto kondisi tanah lapang untuk pembangunan Pojok Dilan, kemudian pada berita ketiga yang berjudul "Polemik Pembangunan Dilan Corner, DPRD Jabar: Batalkan Saja" menggunakan foto Ridwan Kamil. Gambar yang digunakan ketiga berita dari news.detik.com/jawabarat diambil dari wartawan detik.com itu sendiri.

Berdasarkan pemaparan penjelasan foto yang digunakan oleh masing-masing media, kedua media menerapkan nilai kelayakan foto jurnalistik yaitu atas dasar nilai orang yang berkepentingan, aktual, dan sebagai informasi. Namun, penggunaan foto Ridwan Kamil pada berita pikiranrakyat.com.com yang dianalisis bermaksud untuk memberikan kemenonjolan dari apa dan siapa yang diberitakan. Sama halnya dengan news.detik.com/jawabarat yang juga menyesuaikan dengan fungsi dari foto jurnalistik itu sendiri, hanya saja penggunaan foto yang lebih variatif menjadikannya tidak terlalu menonjolkan tokoh tertentu.

Secara keseluruhan pembingkaian berita yang dilakukan oleh pikiranrakyat.com pada pemberitaan pembangunan Pojok Dilan menunjukkan 
bahwa pembangunan Pojok Dilan adalah pembangunan yang bermanfaat bagi masyarakat di Kota Bandung karena menekankan pada aspek positif dari pembangunan Pojok Dilan ini. Sedangkan pada pembingkaian berita yang dilakukan oleh news.detik.com/jawabarat lebih menunjukkan sikap kontra terhadap pembangunan Pojok Dilan karena memperlihatkan sisi kebutuhan realitas sebenarnya.

\subsection{Konstruksi Sosial Media pikiran- rakyat.com}

Dengan meninjau dari teori konstruksi realitas sosial, peneliti menemukan bahwa pikiran-rakyat.com dalam pemberitaanya mengenai pembangunan Pojok Dilan hampir menampilkan realitas yang ada dengan dengan sudut pandang yang berbeda pada setiap berita yang ditampilkan pikiran-rakyat.com, kutipan atau sumber yang digunakan lebih banyak dari pihak Ridwan Kamil dan pejabat struktural di bawah pemerintahannya, walaupun terdapat juga dari pihak yang lainnya atau ahli terkait. Namun setelah menganalisis semua berita yang ada di pikiran-rakyat.com mengenai keterkaitan kebijakan Ridwan Kamil, peneliti menemukan bahwa berita yang ditampilkan pikiran-rakyat.com memiliki tingkat objektivitas yang rendah. Karena pikiranrakyat.com cenderung subjektif memberitakan pembangunan Pojok Dilan ini, terlihat dari sisi pemilihan narasumber yang cenderung dari satu pihak yaitu pemerintahan provinsi Jawa Barat, sehingga tidak menunjukkan netralitas sebagai media dengan tagline dari rakyat, oleh rakyat, dan untuk rakyat.

Kemudian dalam menafsirkan berita, pikiran-rakyat.com terlihat dari pemberitaan bahwa kebijakan Ridwan Kamil dalam membangun Pojok Dilan menunjukkan manfaat bagi masyarakat. Ridwan Kamil menekankan pada pembangunan Pojok Dilan merupakan bukan suatu masalah yang perlu dibesarbesarkan karena pihak Ridwan Kamil melihat ada sisi manfaat yang diberikan. Pikiran-rakyat.com terlihat cenderung menonjolkan hanya dari satu sisi. Realitas yang diciptakan oleh pikiran-rakyat.com terbentuk sejak dilakukannya jumpa pers Ridwan Kamil bersama pemain Dilan dan juga turut serta dihadiri Menteri Pariwisata Arief Yahya, sehingga wawancara saat jumpa pers tersebut dijadikan inti utama dalam pemberitaan sehingga terciptalah suatu realitas yang dikonstruksi oleh pikiran-rakyat.com. Proses pengkontruksian realitas menurut Berger dan Luckmann (dalam Bungin, 2008: 14) terdiri dari tiga proses yaitu eksternalisasi, objektivasi, dan internalisasi.

Dalam pemberitaan pembangunan Pojok Dilan oleh kebijakan Ridwan Kamil ini, proses eksternalisasi terjadi ketika news.detik.com/jawabarat itu sendiri berusaha memaknai isu yang terjadi dalam isu pembangunan Pojok Dilan ini. Selanjutnya proses objektivasi yang dilakukan pikiran-rakyat.com melalui wartawan yang menciptakan berita kemudian media pikiran-rakyat.com memberitakan tentang pembangunan Pojok Dilan yang dicanangkan oleh Ridwan Kamil dengan alasan Pojok Dilan untuk meningkatkan literasi dan pengetahuan film bagi masyarakat di Kota Bandung khususnya kaum milenial. Sehingga masyarakat mulai mengikuti pemberitaan yang diberitakan oleh pikiran-rakyat.com sejak isu tersebut muncul. Yang ketiga adalah proses interialisasi, yaitu ketika wartawan mulai memaknai bahwa isu pembangunan Pojok Dilan yang di gagas Ridwan Kamil ini bermanfaat dan mengandung nilai budaya kontemporer yang baik bagi masyarakat sehingga dengan pengkontruksian realitas ini mengajak masyarakat untuk memiliki pandangan yang sama dengan pikiran- 
Website: https://ojs.unikom.ac.id/index.php/common

DOI Jurnal: https://doi.org/10.34010/common

DOI Artikel: https://doi.org/10.34010/common.v4i1.2688

rakyat.com, yaitu memandang bahwa kebijakan pembangunan Pojok Dilan yang dibuat oleh Ridwan Kamil adalah kebijakan yang positif.

Berdasarkan proses terbentuknya konstruksi sosial media massa (Bungin, 2008: 195), melalui tiga tahap yaitu penyiapan materi konstruksi, penyebaran konstruksi, pembentukan konstruksi realitas, dan tahap konfirmasi. Peneliti menemukan bahwa dari semua pemberitaan yang ditampilkan, pikiran-rakyat.com memiliki kepentingan umum dengan sudut pandang tertentu untuk memberikan informasi kepada masyarakat dengan sudut pandang positif mengenai isu pemberitaan pembangunan Pojok Dilan. Namun kepentingan umum terhadap masyarakat seolah tertutup pemberitaanya karena cenderung memihak pada pihak tertentu karena penekanan yang dilakukan. Dalam hal ini memihak kepada Ridwan Kamil selaku penggagas pembangunan Pojok Dilan. Selanjutnya tahap penyebaran adalah ketika pikiran-rakyat.com menyebarkan informasi mengenai isu pembangunan Pojok Dilan, bahwa pembangunan yang digagas Ridwan Kamil ini akan bermanfaat bagi masyarakat Kota Bandung dalam hal budaya serta pariwisata. Sehingga pandangan masyarakat dibatasi agar memiliki pandangan seperti yang pikiran-rakyat.com lakukan. Yang ketiga adalah pembentukan konstruksi terjadi ketika pikiranrakyat.com mengkonstruksi bahwa gagasan pembangunan Pojok Dilan tidak akan mengambil lahan yang luas sehingga tidak membutuhkan anggaran yang besar, sehingga masyarakat tidak perlu khawatir. Tahap konfirmasi terjadi ketika masyarakat menginginkan untuk mengetahui pemberitaan tentang isu tersebut sehingga masyarakat tertarik membaca berita di pikiran-rakyat.com dan memperoleh informasi menjadi sebuah kebutuhan.

\subsection{Konstruksi news.detik.com/jawabarat \\ Media}

Merujuk pada teori konstruksi sosial, news.detik.com/jawabarat membentuk realitas hampir mendekati keadaan realitas yang sebenarnya dengan sudut pandang yang bervariatif juga. Dimana pada setiap berita yang ditampilkan news.detik.com/jawabarat, kutipan atau sumber yang digunakan berbeda-beda sehingga memperlihatkan dari berbagai sudut pandang. Hanya saja news.detik.com/jawabarat cenderung menampilkan sudut pandang dari narasumber yang kontradiktif. Hal ini terlihat dari keterangan beberapa narasumber yang dipilih berkaitan dengan isu pembangunan Pojok Dilan ini. Media news.detik.com/jawabarat

mengkonstruksikan peristiwa ini dan menafsirkan bahwa kebijakan Ridwan Kamil dalam membangun Pojok Dilan dengan alasan literasi dan film dinilai tidak logis karena penggunaan tokoh Dilan yang fiktif. Kalimat tersebut didukung atas dasar pernyataan Irfan Suryanagara selaku Wakil Ketua DPRD Jawa Barat itu sendiri yang menyatakan bahwa pembangunan Pojok Dilan tidak mengandung nilai budaya untuk Jawa Barat serta Dilan yang merupakan tokoh fiktif dan bukan merupakan tokoh yang memberi kontribusi bagi Jawa Barat. Berdasarkan penjelasan sebelumnya, news.detik.com/jawabarat kebanyakan menggunakan narasumber dari sisi yang kontra sehingga menonjolkan pernyataan tidak setuju dengan kebijakan dari Ridwan Kamil.

Dalam melakukan konstruksi, news.detik.com menggunakan teori dari Berger dan Luckmann (Bungin, 2008: 14) yaitu melalui tiga proses yaitu eksternalisasi, objektivasi, dan internalisasi yang pada intinya untuk menggambarkan konstruksi realitas sosial sebagai proses sosial melalui tindakan dan interaksi untuk 
menciptakan suatu realitas secara subjektif. Eksternalisasi adalah proses ekspresi diri manusia ke dalam dunia, dalam hal ini adalah ketika wartawan atau news.detik.com/jawabarat berusaha mencari tahu dan memaknai isu pembangunan Pojok Dilan sebagai sebuah masalah. Kemudian objektivasi merupakan kelanjutan dari proses eksternalisasi, dimana dalam hal ini news.detik.com/jawabarat memberitakan isu pembangunan Pojok Dilan melalui perspektif kontra. Kemudian isu ini menjadi lebih besar karena news.detik.com/jawabarat menanggapi isu tersebut sebagai sebuah ketidakadilan bagi masyarakat. Sehingga disusul dengan tanggapan beberapa pihak kritikus terkait. Selanjutnya tahap terakhir yaitu internalisasi, ketika wartawan memandang kebijakan Ridwan Kamil dalam membangun Pojok Dilan tidak logis dan tidak adil sehingga masyarakat yang mengikuti pemberitaan dari awal akan memihak pada apa yang telah diberitakan news.detik.com/jawabarat.

Berdasarkan proses terbentuknya konstruksi sosial media massa (Bungin, 2008: 195), melalui tiga tahap yaitu penyiapan materi konstruksi, penyebaran konstruksi, pembentukan konstruksi realitas, dan tahap konfirmasi. Dari semua berita yang ditampilkan, news.detik.com/jawabarat melakukan tahap penyiapan konstruksi yaitu news.detik.com/jawabarat memiliki kepentingan tersendiri untuk memberitakan kebijakan Ridwan Kamil dalam membangun Pojok Dilan, dimana peneliti melihat bahwa pemberitaan yang dilakukan oleh news.detik.com/jawabarat didasari atas kepentingan umum yang berarti untuk kebutuhan masyarakat dalam memperoleh informasi tentang berita tersebut. Tahapan penyebaran informasi terjadi ketika news.detik.com/jawabarat memberitakan kritik korban banjir terkait pembangunan
Pojok Dilan yang digagas oleh Ridwan Kamil. Dalam pemberitaan tersebut, kritik masyarakat ini mewakili suara masyarakat yang kontra terhadap pembangunan tersebut. Dalam tahap ini, news.detik.com/jawabarat mencoba menampilkan konstruksinya melalui berita tersebut agar khalayak lainnya memiliki pandangan yang sama. Tahap pembentukan ialah ketika news.detik.com/jawabarat mengkonstruksi berita hampir mendekati realitas sebenarnya yaitu dengan menunjukkan kondisi sebenarnya dari pembangunan Pojok Dilan yang menjadi polemik. Selain itu news.detik.com/jawabarat memberikan informasi dari berbagai sumber di setiap berita. Secara keseluruhan berita dari news.detik.com/jawabarat berusaha menggiring opini bahwa kebijakan Ridwan Kamil tidak benar. Tahap konfirmasi yaitu ketika media maupun khalayak lainnya memberi argumen untuk terlibat dalam pembentukan konstruksi ketika masyarakat haus akan informasi.

\section{Kesimpulan dan Rekomendasi}

Berdasarkan pada pemaparan hasil analisis, maka dapat penulis tarik kesimpulan bahwa media online pikiranrakyat.com dan news.detik.com/jawabarat dalam menyajikan berita seputar isu pembangunan Pojok Dilan oleh Ridwan Kamil memiliki cara yang berbeda dalam melakukan pembingkaian berita. Cara penyampaian berita yang dilakukan masing-masing media berbeda dengan tujuan untuk membangun opini dan persepsi para pembaca dalam melihat isu pembangunan Pojok Dilan oleh Gubernur Ridwan Kamil dan menyesuaikan dengan yang diinginkan oleh masing-masing dari media. Berdasarkan dari hasil penelitian yang telah penulis lakukan, kesimpulan yang dapat ditarik adalah: 
1. Ditinjau dari struktur sintaksis, media online pikiran-rakyat.com menggunakan judul berita yang menggambarkan inti dari berita tanpa adanya kutipan langsung dari narasumber dengan kalimat yang terkesan biasa saja dan sudah membuat kesimpulan di judulnya, sedangkan news.detik.com/jawabarat menggunakan judul berita yang juga menggambarkan kesimpulan dari isi berita dan terkesan lebih provokatif dan menarik perhatian pembaca karena ada berita yang menggunakan kutipan langsung dari narasumber. Narasumber yang dipilih news.detik.com/jawabarat itu sendiri bervariatif berbeda dengan pikiran-rakyat.com yang lebih menonjolkan satu pihak yaitu Ridwan Kamil. Kemudian pernyataan yang disampaikan oleh narasumber di pikiran-rakyat.com terlihat mengajak masyarakat untuk sepakat dengan kebijakan Ridwan Kamil dalam membangun Pojok Dilan, sedangkan news.detik.com/jawabarat terlihat memprovokasi masyarakat untuk tidak menyetujui kebijakan yang digagas Ridwan Kamil karena pada dasarnya news.detik.com/jawabarat ingin menegakkan keadilan bagi masyarakat.

2. Ditinjau dari struktur skrip, berita pada pikiran-rakyat.com dan news.detik.com/jawabarat sudah memenuhi unsur berita $5 \mathrm{~W}+1 \mathrm{H}$. Teks berita di pikiran-rakyat.com cenderung hanya melihat ke arah Ridwan Kamil saja terkait isu pembangunan Pojok Dilan ini sedangkan berita-berita pada news.detik.com/jawabarat terlihat mengambil sudut pandang dari berbagai pihak sehingga berita berita yang disajikan lebih netral, netral yang dimaksud ialah mementingkan kepentingan publik. Jika dilihat dari waktu terbitnya berita, berita-berita pada media online pikiran.rakyat.com lebih cepat terbitnya dibandingkan berita pada news.detik.com/jawabarat.

3. Ditinjau dari segi tematik, isi berita pada pikiran-rakyat.com cenderung mengangkat tema terkait tanggapan Ridwan Kamil dalam hal pembangunan Pojok Dilan di Kota Bandung. sedangkan berita pada news.detik.com/jawabarat tidak hanya menanggapi tanggapan Ridwan Kamil tetapi lebih memperlihatkan tanggapan masyarakat, pakar terkait, dan DPRD Jawa Barat mengenai pembangunan Pojok Dilan yang tidak memiliki nilai urgensi.

4. Ditinjau dari struktur retoris, bahasa yang digunakan keduanya yaitu bahasa yang provokatif. Hanya saja, pikiranrakyat.com.com lebih banyak menggunakan bahasa provokatif daripada news.detik.com/jawabarat. Kemudian gambar yang dipakai pada berita di pikiran-rakyat.com.com semuanya fotonya terdapat wajah Ridwan Kamil. Hal ini menggambarkan bahwa tokoh penting dalam isu pembangunan Pojok Dilan ini memang Ridwan Kamil. Sedangkan gambar yang dipakai news.detik.com/jawabarat lebih bervariatif. Hal ini menunjukkan gambar yang dipakai sesuai dengan isi berita yang disajikan yaitu berbicara tentang kontra terhadap isu pembangunan Pojok Dilan.

\section{Daftar Pustaka}

\section{Sumber buku}

Bungin, B. (2008). Konstruksi Sosial Media Massa: Kekuatan Pengaruh Media Massa, Iklan Televisi, dan Keputusan Konsumen Serta Kritik Terhadap Peter I. Berger \& Thomas Luckmann. Jakarta: Kencana. 
Eriyanto. (2012). Analisis Framing. Yogyakarta: LKiS Group.

Muhtadi, D. H. (2016). Pengantar Ilmu Jurnalistik. Bandung: Simbiosa Rekatama Media.

Musman, A., \& Mulyadi, N. (2017). Jurnalisme Dasar Panduan Praktis Para Jurnalis. Yogyakarta: KOMUNIKA.

Santana, S. (2005). Jurnalisme Kontemporer. Jakarta: Yayasan Obor Indonesia.

Sumadiria, D. A. (2005). Jurnalistik Indonesia:Menulis Berita dan Feature Panduan Praktis Jurnalis Profesinal. Bandung: Simbiosa Rekatama Media.

Tumber, H. (1999). News: A Reader. New York: Oxford University Press.

Vera, N. (Bogor). Komunikasi Massa. 2016: Ghalia Indonesia.

\section{Sumber internet}

$\mathrm{NN}$.

Dilan

1991.

http://filmindonesia.or.id/movie/titl e/lf-d009-19-938216 dilan1991\#.XMk3mjAzbDc, diakses pada tanggal01/05/19, 9:20 WIB

$\mathrm{NN}$.

Dilan

1991.

http://filmindonesia.or.id/movie/titl e/lf-d009-19-938216 dilan1991\#.XMk3mjAzbDc, diakses pada tanggal01/05/19, 9:20 WIB
Ramdhani, D. Proyek Pojok Dilan Sepaket dengan Taman Saparua, Telan Dana Rp $\quad 4,8 \quad$ Miliar. https://bandung.kompas.com/read/ 2019/03/06/12255591/proyekpojok-dilan-sepaket-dengan-tamansaparua-telan-dana-rp-48miliar?page $=$ all, diakses pada tanggal 08/01/20, 19:36 WIB

Ranawati, N. K. Melalui Akunnya, Emil Tanggapi Kontroversi Pojok Dilan. https://www.ayobandung.com/read /2019/03/01/46007/melaluiakunnya-emil-tanggapikontroversi-pojok-dilan, diakses pada tanggal 12/03/19, 12:55 WIB

Rizal, E. M. Sudut Dilan, Refleksi Upaya Wisata Melalui Literasi dan Film. https://mediaindonesia.com/read/de tail/218988-sudut-dilan-refleksiupaya-wisata-melalui-literasi-dan-

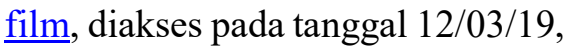
13:18 WIB

Solehudin, M. Pembangunan Dilan Corner Ridwan Kamil, Antara Lebay dan Politis.

Dipetik https://news.detik.com/berita-jawabarat/d-4445627/pembangunandilan-corner-ridwan-kamil-antaralebay-dan-politis, diakses pada tanggal 12/03/19, 9:38 WIB

Solehudin, M. Ridwan Kamil Bangun Dilan Corner, Pengamat: Kebijakan Lebay.

https://news.detik.com/berita-jawabarat/d-4444667/ridwan-kamilbangun-dilan-corner-pengamatkebijakan-lebay/komentar, diakses pada tanggal 12/03/19, 12:37 WIB 